\title{
BINDING OF A NON-IONIC AZO DYE BY SODIUM SALT OF $\beta$-NAPHTHALENESULFONIC ACID-FORMALDEHYDE CONDENSATES. - EFFECT OF THE DEGREE OF THE CONDENSATION ON THE BINDING EQUILIBRIUM
}

\author{
By Takao Shibusawa \\ (College of Technology, Gunma University, \\ 1-5-1, Tenjin-cho, Kiryu-shi 376, Japan)
}

\begin{abstract}
The binding of a model azo disperse dye by $\beta$-naphthalenesulfonic acid and formaldehyde condensates $(\beta \mathrm{NSF})$ in water was discussed. The binding constants, $K$, for the birfing by $\beta$ NSF with different degrees of condensation, $N=2,3,4,5,7.2,12$ and 40 were determined spectrophothometrically. The thermodynamic parameters, the enthalpy change, $\Delta H^{\circ}$ and the entropy change, $\Delta S^{\circ}$ calculated from the values of $K$ in the temperature range $15-40^{\circ} \mathrm{C}$ revealed following facts.

The value of $K$ increases with $N$ up to $N=$ ca. 10 and then level off gradually. This is ascribed to an increase in $\Delta S^{\circ}$ with $N$; the value is negative for $\beta$ NSF with $N=2,3$ and 4 but it becomes positive for $\beta \mathrm{NSF}$ with $N=12,40$ under the low concentration of added salts. The value of $\Delta H^{\circ}$ is negative irrespective of $N$ but its absolute value decreases with the increase in $N$.

The increase in the concentration of added salts gives no appreciable change in the thermodynamic parameters for $\beta$ NSF with $N=3$ but for $\beta$ NSF with $N=12$ and 40 , the increase gives significant changes in the parameters; both values of $\Delta H^{\circ}$ and $\Delta S^{\circ}$ decrease significantly. These results may be explained in terms of the conformational change of polyelectrolytes. $\beta$ NSF with $N=12$ and 40 behave as a typical polyelectrolyte; their conformation varies from an expanded form to a compact one on addition of electrolytes. The extended conformation is favorable for the hydrophobic interaction between the linear dye and successive naphthalene nuclei of $\beta$ NSF with a high degree of the condensation. The increase in the value of $\Delta S^{\circ}$ with $N$ may be explained in terms of the contribution of the hydrophobic bonding to the binding.
\end{abstract}

\section{Introduction}

The sodium salt of $\beta$-naphthalenesulfonic acid and formaldehyde condensates (abbreviated as $\beta$ NSF) has been used as a dispersing agent in the production and use of disperse and vat dyes ${ }^{1)}$. Hattori and co-workers have studied the structure and properties of $\beta$ NSF in detail ${ }^{2-4)}$. They reported that 1) the most probable structure of $\beta$ NSF is represented by $[1]^{2)}$ and commercial. products are a mixture of the condensates with $N=2-9^{3,5}$. 2) the dispersing power of $\beta \mathrm{NSF}$ for fine powders of zinc white and a vat dye increases with $N$ up to $N=9$ and $5^{4)}$ and 3) the condensates with $N>5$ behave as a polyelectrolyte

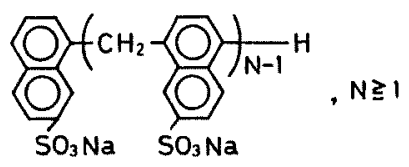

[I]

in water ${ }^{4)}$. Valko pointed out that the polymeric structure is preferable as a dispersing agent ${ }^{6}$.

We have already studied the interaction between $\beta$ NSF $(N=12)$ and some disperse dyes in water through the measurements of the binding conatants and discussed the binding equilibrium in terms of the thermodynamic parameters ${ }^{7)}$. In this paper, the effect of the degree of condensation of $\beta \mathrm{NSF}$ on the binding constant of a model azo disperse 
dye will be discussed on the thermodynamic parameters of the binding.

\section{Experimentals}

\subsection{Materials}

The dye used (Dye 1) [II] was prepared by diazotizing aniline and coupling with $\mathrm{N}, \mathrm{N}-\mathrm{Di}(2-$ hydroxyethyl)toluidine, followed by purification by repeated recrystallizations from water; m.p. = $111-112^{\circ} \mathrm{C}, \mathrm{pKa}=3.53\left(25^{\circ} \mathrm{C}\right)$.

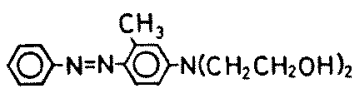

[II]

$\beta$ NSF ( $N=1-c a .12)$ was prepared by the reaction of one mole of $\beta$-naphthalenesulfonic acid $(\beta \mathrm{NSA})$ and 0.8 mole of formaldehyde (FA) as reported by Hattori and Tanino ${ }^{3)}$. $\beta$ NSF ( $N=$ 1 -ca.40) was prepared similarly from equimolar amounts of $\beta$ NSA and FA. By means of fractional precipitation*, the condensates were fractionated into five divisions, i.e., $N=1-3, N=3-5, N=6-8$, $N=12(N>9)$ and $N=40(N>9)$. For the fractions with $N>9$, the average value of $N$ was estimated from the viscometric measurements ${ }^{4}$ and for the fractions with $N<9$, the values of $N$ were determined from the TLC tests on micro crystalline cellulose powder (Tokyo Kasei Co.) by using a mixture of $\mathrm{n}$-buthanol, acetic acid and water (4:1:2 in volume) as solvent. Each spot on the plate was detected by spraying aqueous solution of C.I. Basic Red 13.

Monodisperse $\beta$ NSF samples with $N=1-5$ were isolated from the fraction including $N=1,2$ and 3 and that including $N=3,4$ and 5 , by means of the column chromatography on cellulose powder; the eluent used were water saturated buthanol for the former fraction, and a mixture of buthanol, water and acetic acid (6:2:1 in volume) for the later. The effluent from the outlet of the column was passed in a flow cell in a photometer and the concentration of $\beta$ NSF isolated in the effluent was detected by the UV absorption at $325 \mathrm{~nm}$.

\subsection{Measurements and Calculations}

Absorption spectra were recorded on a Simadzu MPL-50L spectrophotometer equipped with a

* The solubility of $\beta$ NSF in water increases with the increase in $N$, whereas that in ethanol decreases with the increase in $N$. thermostated housing; the temperature of the solution in the cell (path length $=1 \mathrm{~cm}$ ) was controlled at $16.0,20.0,25.0,30.0$ and $35 \pm 0.1^{\circ} \mathrm{C}$.

Viscosities were measured by using two Ubbelohde type viscometers with flow times for water of 157 and $250 \mathrm{~s}$, respectively; the temperature was controlled at $25 \pm 0.02^{\circ} \mathrm{C}$.

Calculations were made on an NEC PC-9801 VMO personal computer using relevant calculation programs.

\section{Results and Discussion}

Figs. 1 and 2 show the change in the absorption spectrum of Dye 1 in aqueous solution by the addition of $\beta$ NSF with $N=2$ and 12 , respectively. As seen in each figure, the absorption peak at $453 \mathrm{~nm}$ decreases and the absorption at about $550 \mathrm{~nm}$ increases as the concentration of $\beta$ NSF is increased. Similar spectral changes were also observed for $\beta$ NSF with different $N$. The absorption curves obtained for a series of measurements for the dye - a $\beta$ NSF systems passed through an isosbestic point as exemplified by the curves in Figs. 1 and 2 ; the point tends to shift to longer wavelength with $N$ of $\beta \mathrm{NSF}$. These findings

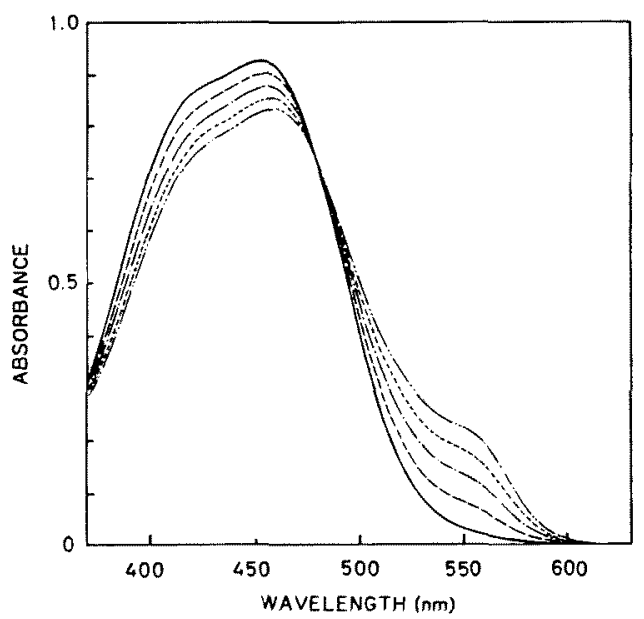

Fig. 1 Change in the absorption spectrum of Dye 1 as a function of the concentration of $\beta \mathrm{NSF}$ with $\mathrm{N}=2$ at $20^{\circ} \mathrm{C}, \mathrm{pH}=5.58$ $(0.02 \mathrm{~mol} / \mathrm{l}$ acetate buffer $)$.

Concentration of Dye 3: $4.00 \times 10^{-5} \mathrm{~mol} / 1$

Concentration of $\beta$ NSF with $N=1$ (base mol/1)

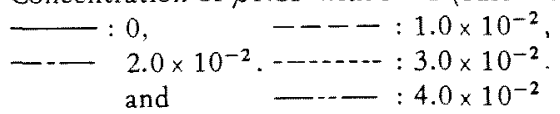




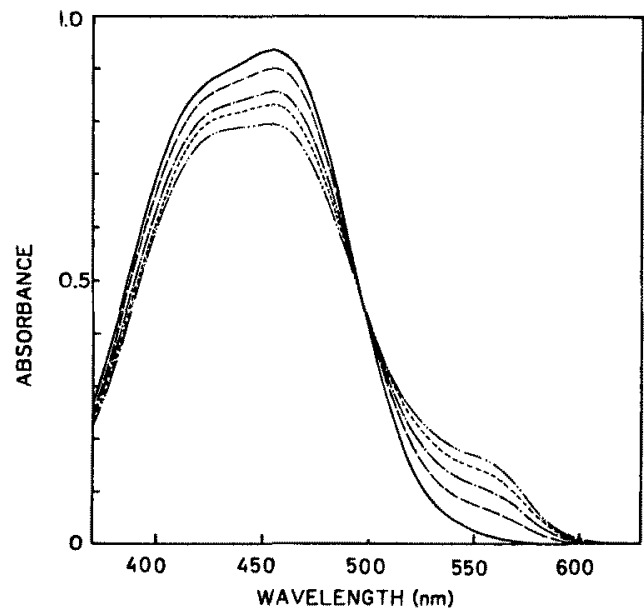

Fig. 2 Change in the absorption spectrum of Dye 1 as a function of the concentration of $\beta \mathrm{NSF}$ with $N=12$ at $20^{\circ} \mathrm{C}, \mathrm{pH}=5.58$ $(0.02 \mathrm{~mol} / \mathrm{l}$ acetate buffer $)$.

Concentration of Dye 1: $4.00 \times 10^{-5} \mathrm{~mol} / 1$ Concentration of $\beta \mathrm{NSF}$ with $\mathrm{N}=12$ (base $\mathrm{mol} / \mathrm{l}$ )

$$
\begin{aligned}
- & 0, \\
- & 8.0 \times 10^{-5}, \\
& \text { and }
\end{aligned}
$$

indicate that the spectral changes shown in Figs. 1 and 2 are a result of the binding of Dye 1 by $\beta$ NSF. Here we express the binding equilibrium by Eqs. 1 and 2.

free dye + free site in $\beta$ NSF $\stackrel{K}{=}$ bound dye

$$
\begin{array}{cc}
(a-x) \quad(n P-x) & (x) \\
\left(\lambda_{\max }=453 \mathrm{~nm}\right) & \left(\lambda_{\max }=\mathrm{ca} .550 \mathrm{~nm}\right)
\end{array}
$$

$$
K=\frac{x}{(a-x)(n P-x)}
$$

where, $K$ is the binding constant, $n$ is the number of binding site in monomeric unit of $\beta$ NSF (it was found that $n=1$ for Dye $1^{7)}, P$ is the concentration of $\beta$ NSF (monomeric unit basis), $a$ is the initial concentration of dye and $x$ is the concentration of bound dye.

By assigning $\varepsilon_{\mathrm{b}}, \varepsilon_{\mathrm{f}}$ and $\varepsilon_{\mathrm{app}}$ as molar absorptivities of bound dye, free dye and apparent molar absorptivity of dye solution in the presence of $\beta$ NSF at a wavelength of $\lambda$, where the value of $\varepsilon_{\text {app }}$ is increased greatly by the binding. Eq. 2 is rewritten into $\mathrm{Eq} .3$ as,

$$
\varepsilon_{\mathrm{app}}=-\frac{\left(\varepsilon_{\mathrm{app}}-\varepsilon_{\mathrm{f}}\right)\left(\varepsilon_{\mathrm{b}}-\varepsilon_{\mathrm{f}}\right)}{n P\left(\varepsilon_{\mathrm{b}}-\varepsilon_{\mathrm{f}}\right)-a\left(\varepsilon_{\mathrm{app}}-\varepsilon_{\mathrm{f}}\right)} \cdot \frac{1}{K}+\varepsilon_{\mathrm{b}}
$$

Eq. 3 indicates that the plot of $\varepsilon_{\text {app }}$ against $\left(\varepsilon_{\text {app }}-\varepsilon_{\mathrm{f}}\right)\left(\varepsilon_{\mathrm{b}}-\varepsilon_{\mathrm{f}}\right) /\left\{n P\left(\varepsilon_{\mathrm{b}}-\varepsilon_{\mathrm{f}}\right)-a\left(\varepsilon_{\mathrm{app}}-\varepsilon_{\mathrm{f}}\right)\right\}$ gives a straight line with the slope, $-1 / K$, and the intercept, $\varepsilon_{\mathrm{b}}$. $\varepsilon_{\mathrm{f}}$ and $\varepsilon_{\mathrm{app}}$ are determined experimentally. Starting with an approximate value of $\varepsilon_{\mathrm{b}}$, close values of $-1 / K$ and $\varepsilon_{\mathrm{b}}$ are determined by the iterative method.

Fig. 3 shows examples of the plots of Eq. 3 converged to the limiting values. Each plot falls on a straight line over the concentration ranges of $\beta$ NSF used. The values of $K$ were evaluated by means of the least square method. The binding constants for $\beta$ NSF with various $N$ at $15-40^{\circ} \mathrm{C}$ were determined from the similar plots.

Table 1 shows the effect of the degree of condensation on the thermodynamic parameters of the binding; the enthalpy change, $\Delta H^{\circ}$, and the entropy change, $\Delta S^{\circ}$, were calculated using the standard thermodynamic relations. The numerical values given in Table 1 indicate that the binding occurs mainly by the contribution of the negative enthalpy term, but this contribution decreases with $N$. On the other hand, the entropy term gives negative contribution for the binding by $\beta \mathrm{NSF}$ with $N<5$ but the value of $\Delta S^{\circ}$ increases with $N$ and becomes to give a positive contribution to the binding for $\beta$ NSF with $N>7$. Fig. 4 indi-

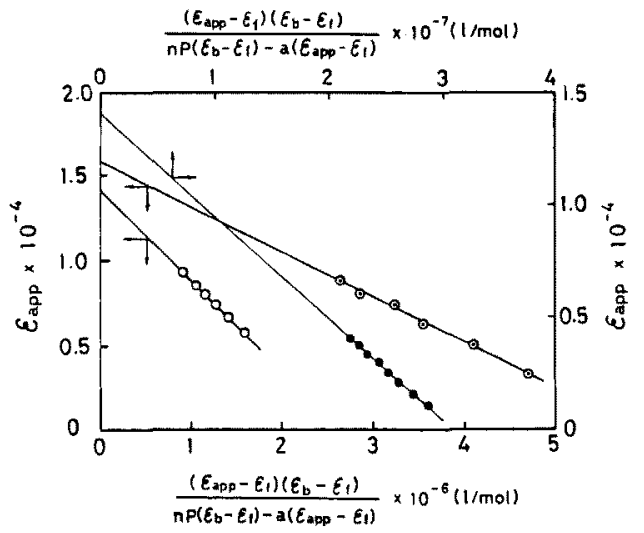

Fig. 3 Plots of Eq. 3 for the binding of Dye 1 by fractionated $\beta$ NSF.

Degree of condensation of $\beta \mathrm{NSF}(N)$ and the wavelength used for the plots

$\bigcirc-N=4(\lambda=545 \mathrm{~nm}),-\odot-N=5(\lambda=$ $545 \mathrm{~nm})$ and $-N=12(\lambda=550 \mathrm{~nm})$

Concentration of Dye $1: 4.0 \times 10^{-5} \mathrm{~mol} / 1$

Temperature $=20.0^{\circ} \mathrm{C}, \quad \mathrm{pH}=5.58 \quad(0.02 \mathrm{~mol} / 1$ acetate buffer 
Table 1 Effect of the degree of condensation of $\beta$ NSF $(N)$ on the thermodynamics of the binding of Dye 1 by $\beta$ NSF

\begin{tabular}{|c|c|c|c|c|c|}
\hline$N$ & $\begin{array}{c}\mathrm{pH} \\
(25 \mathrm{C})\end{array}$ & $\begin{array}{c}\text { Temp. } \\
(\mathrm{c})\end{array}$ & $K \times 10^{-2} *$ & $\begin{array}{c}\Delta H^{\circ} \\
(\mathrm{kcal} / \mathrm{mol})\end{array}$ & $\begin{array}{c}\Delta S^{\circ} \\
(\text { e.u. })\end{array}$ \\
\hline 2 & \multirow{6}{*}{5.58} & $\begin{array}{l}15.0 \\
20.0 \\
25.0 \\
30.0\end{array}$ & $\begin{array}{l}2.64 \\
2.16 \\
1.82 \\
1.48\end{array}$ & -6.66 & -120 \\
\hline 3 & & $\begin{array}{l}15.0 \\
20.0 \\
25.0 \\
30.0\end{array}$ & $\begin{array}{l}25.3 \\
20.9 \\
17.1 \\
14.4\end{array}$ & -6.53 & -7.10 \\
\hline 4 & & $\begin{array}{l}15.0 \\
20.0 \\
25.0 \\
30.0 \\
\end{array}$ & $\begin{array}{c}123 \\
106 \\
82.2 \\
71.7 \\
\end{array}$ & -6.56 & -4.02 \\
\hline 5 & & $\begin{array}{l}15.0 \\
20.0 \\
25.0 \\
30.0 \\
\end{array}$ & $\begin{array}{l}277 \\
239 \\
189 \\
166 \\
\end{array}$ & -6.19 & -123 \\
\hline $7.2^{* * *}$ & & $\begin{array}{l}15.0 \\
20.0 \\
25.0 \\
30.0\end{array}$ & $\begin{array}{l}712 \\
589 \\
503 \\
433\end{array}$ & -5.73 & 2.28 \\
\hline 12 & & $\begin{array}{l}15.0 \\
20.0 \\
25.0 \\
30.0 \\
35.0\end{array}$ & $\begin{array}{r}1530 \\
1340 \\
1230 \\
1060 \\
929 \\
\end{array}$ & -436 & 8.62 \\
\hline 40 & 5.50 & $\begin{array}{l}15.0 \\
20.0 \\
25.0 \\
30.0 \\
35.0\end{array}$ & $\begin{array}{l}3190 \\
2790 \\
2400 \\
2170 \\
1970\end{array}$ & -4.54 & 9.09 \\
\hline
\end{tabular}

* The binding constants were determined in the presence of $0.02 \mathrm{~mol} / 1$ acetate buffer and calculated on mole fraction basis.

** Consists of a large amount of $\beta$ NSF with $N=7$ and small amounts of $\beta$ NSF with $N=6$ and 8 .

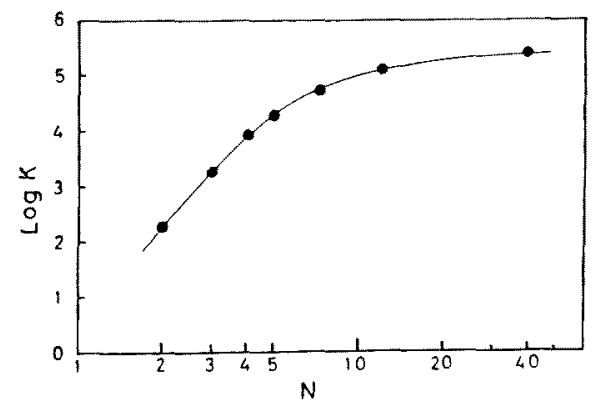

Fig. 4 Relation between the binding constant, $K$, and the degree of condensation of $\beta \mathrm{NSF}$, $N$, for Dye 1 at $25^{\circ} \mathrm{C}, \mathrm{pH}=5.58(0.02 \mathrm{~mol} / 1$ of acetate buffer). cates that the value of $K$ increases rapidly with $N$ up to about $N=10$ and then approaches a levels off value gradually. A similar change in binding constant with $N$ has been found for the binding of Congo Red (C. I. Direct Red 28) by amylose and amylodextrines ${ }^{8)}$.

It has been reported that the dispersing power of $\beta \mathrm{NSF}$ increases with $N$ up to $N=5-9^{4)}$. It is worthwhile to note here that both the dispersing power and the binding constant increase with $N$ up to $N=$ ca.10. As shown in Table 1 , the later is attributed to increase in $\Delta S^{\circ}$

Figs. 1 and 2 show that the appearance of a new absorption band at about $550 \mathrm{~nm}$ on the binding. This suggests the following binding mechanism ${ }^{7)}$.
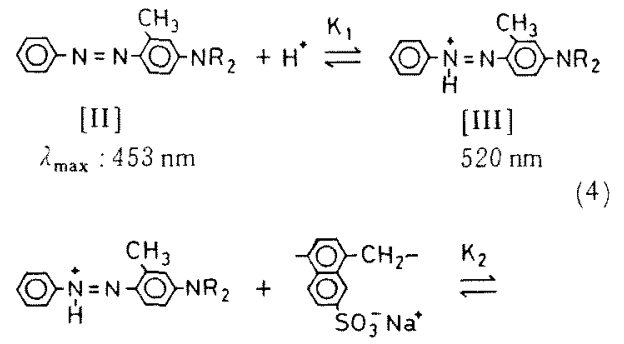

[III]

[I]

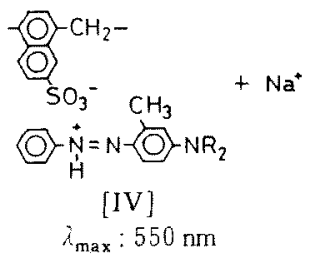

According to the scheme described above, a part of the fixed charges on $\beta$ NSF are neutralized by the binding. The mechanism of the binding will be discussed in detail in a subsequent paper.

Fig. 5 shows the reduced viscosities of $\beta \mathrm{NSF}$ with $N=40$ dissolved in water, $\beta$ NSF with $N=40$ behaves as a flexible chain polyions. In the absence of added salts, $\eta_{\mathrm{sp}} / \mathrm{C}$ increases rapidly on dilution of the solution. A similar change in the viscosity was also observed for $\beta$ NSF with $N=12$. These facts are explained as a result of the expansion of the polyion chains caused by the increase in the electrostatic repulsion between the fixed charges on the polyions due to the decrease in ionic strength of the solution on the dilution. 


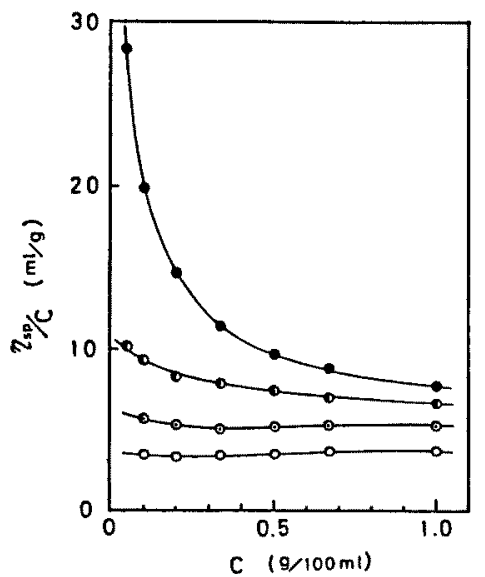

Fig. 5 Effect of electrolyte concentration on the reduced viscosity of $\beta \mathrm{NSF}$ with $N=40$ in water at $25^{\circ} \mathrm{C}$.

Concentration of the added electrolytes

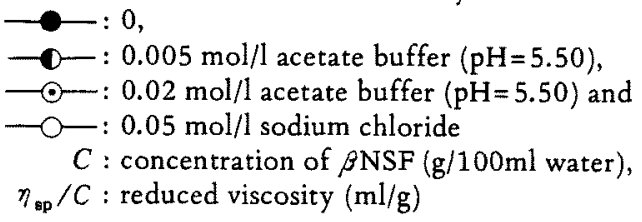

The repulsive power is reduced by addition of electrolytes due to their shielding effect for the fixed charges; the conformation of the polyion varies from a expanded form to a compact one when the concentration of the added salt is increased. Therefore, the limiting value of $\eta_{\mathrm{sp}} / C$ decreases rapidly on addition of electrolytes.

If a part of the fixed charges on $\beta$ NSF is neutralized on the binding and loose their charge as expressed by Eq. 5, the polyion chain conformation becomes more random. This may contribute to increase in $\Delta S^{\circ}$ of the system, particularly for $\beta$ NSF with large $N$ such as $N=12$ or 40 .

At the moment, three possible reasons may be cited for the increase in $\Delta S^{\circ}$ on the dye binding with $N$;

i) release of the electrostricted water molecules in the vicinity of the charged group, ii) an increase in the randomness of the polyion chain conformation and iii) hydrophobic bonding, the release of water molecules from their ordered structure in the vicinity of hydrophobic parts of the dye and $\beta$ NSF.
The reason i) may be unable to explain the increase in $\Delta S^{\circ}$ with $N$ since it seems to be independent of $N$.

If a part of the fixed charge on $\beta$ NSF is neutralized on the binding, the conformation of $\beta N S F$ varies from an expand form to a more compact one. This results in the decrease in $\eta_{\mathrm{sp}} / C$ of the $\beta$ NSF in water; the viscosity of $\beta$ NSF with $N=40$ dissolved in aqueous solution of Dye 1 should be lower than that in water. However, no appreciable differences between the viscosities of $\beta$ NSF with $N=40$ dissolved in water and that in the dye solutions were observed at $25.0^{\circ} \mathrm{C}$; the concentration of Dye 1 was $1.00 \times 10^{-4} \mathrm{~mol} / 1$ (in the absence of electrolytes) and $4.00 \times 10^{-5} \mathrm{~mol} / 1$ (in the presence of 0.005 and $0.02 \mathrm{~mol} / \mathrm{l}$ of acetate buffer, $\mathrm{pH}=5.50$ ), respectively. The binding constants given in Table 1 were determined using $a=4.00 \times 10^{-4} \mathrm{~mol} / 1$ and $P=4-20 \times 10^{-4}$ base $\mathrm{mol} / \mathrm{l}$ in the presence of acetate buffer $(\mathrm{pH}=5.50)$. Under this conditions, the number of bound dye per monomeric unit of $\beta \mathrm{NSF}$ with $N=40$ is calculated to be $0.12-0.08$ at $25^{\circ} \mathrm{C}$. However, in the presence of acetate buffer, which is required for the reproducible measurement of the binding constant, the conformation of $\beta \mathrm{NSF}$ with $N=40$ is already in a fairly compact form as shown in Fig. 5. Consequently, it seems that the further increase in the flexibility of the polyion chain on the binding is small.

Under the conditions of the viscosity measurements, the number of bound dye per monomeric unit of $\beta$ NSF with $N=40$ is estimated to be only 0.017 at the most, e.g. at $C=0.05 \mathrm{~g} / 100 \mathrm{ml}(2.064$ $\times 10^{-3}$ base $\mathrm{mol} / \mathrm{l}$ ) with $K=39301 / \mathrm{mol}^{* *}$ Consequently, it seems that the reason ii) gives a small contribution to the increase in $\Delta S^{\circ}$ with $N$ shown in Table 1.

As is well known, Congo Red is a typical planer and linear dye. The binding constant of Congo Red with amylose and amylodextrines increases with their chain length ${ }^{8)}$ in spite of their helical structure in water ${ }^{9}$. Giles has pointed out that the affinity of planar azo dyes and leuco vat dyes to regenerated cellulose increase linearly with $\log$ (molecular conjugated chain length of dyes) ${ }^{10}$ ).

Dye 1 molecule is linear and the two benzen

** The value determined in the presence of 0.02 mol/l acetate buffer of $\mathrm{pH}=5.50$. 
rings are coplanar, so that the contribution of hydrophobic interaction between Dye 1 and $\beta$ NSF to the binding will become greater when a number of naphthalene nuclei of $\beta$ NSF lie successively linear as shown in Fig. 6. It seems that the main reason for the increase in $\Delta S^{\circ}$ with $N$ is attributable to reason iii); the increase in $\Delta S^{\circ}$ with $N$ may be explained in terms of hydrophobic bonding.

Table 2 shows the effect of added salts on the thermodynamic parameters of the dye binding by

Table 2 Effect of electrolytes on the thermodynamics of the binding of Dye 1 by $\beta$ NSF

\begin{tabular}{|c|c|c|c|c|c|c|}
\hline$N$ & $\begin{array}{l}\text { Concentration } \\
\text { of Electrolyte }\end{array}$ & $\begin{array}{c}\mathrm{pH} \\
(25 \mathrm{C})\end{array}$ & $\begin{array}{l}\text { Temp. } \\
\text { (C) }\end{array}$ & $K \times 10^{-3 *}$ & $\begin{array}{c}\Delta H^{\circ} \\
(\mathrm{kcal} / \mathrm{mol})\end{array}$ & $\begin{array}{c}\Delta S^{\circ} \\
\text { (e.u.) }\end{array}$ \\
\hline \multirow{2}{*}{3} & $\begin{array}{l}0.02 \mathrm{~mol} / \mathrm{l} \\
\text { acetate buffer }\end{array}$ & 5.58 & $\begin{array}{l}15.0 \\
20.0 \\
25.0 \\
30.0\end{array}$ & $\begin{array}{l}2.53 \\
2.09 \\
1.71 \\
1.44\end{array}$ & -6.53 & -7.10 \\
\hline & $\begin{array}{l}0.1 \mathrm{~mol} / \mathrm{l} \\
\text { acetate buffer }\end{array}$ & 5.52 & $\begin{array}{l}16.9 \\
20.0 \\
25.0 \\
30.0 \\
35.0 \\
\end{array}$ & $\begin{array}{l}3.23 \\
2.83 \\
2.35 \\
1.96 \\
1.60 \\
\end{array}$ & -6.79 & -7.35 \\
\hline \multirow{4}{*}{12} & $\begin{array}{l}0.01 \mathrm{~mol} / l \\
\text { acetate buffer }\end{array}$ & 5.59 & $\begin{array}{l}15.0 \\
20.0 \\
25.0 \\
30.0 \\
35.0\end{array}$ & $\begin{array}{l}172 \\
160 \\
144 \\
135 \\
115\end{array}$ & -3.39 & 12.22 \\
\hline & $\begin{array}{l}0.02 \mathrm{~mol} / l \\
\text { aceta te buffer }\end{array}$ & 5.58 & $\begin{array}{l}15.0 \\
20.0 \\
25.0 \\
30.0 \\
35.0\end{array}$ & $\begin{array}{c}153 \\
134 \\
123 \\
106 \\
92.9\end{array}$ & -4.36 & 8.62 \\
\hline & $\begin{array}{l}0.05 \mathrm{~mol} / \mathrm{l} \\
\text { acetate buffer }\end{array}$ & 5.56 & $\begin{array}{l}15.0 \\
20.0 \\
25.0 \\
30.0 \\
\end{array}$ & $\begin{array}{c}167 \\
131 \\
121 \\
95.3 \\
\end{array}$ & -6.11 & 267 \\
\hline & $\begin{array}{l}0.1 \mathrm{~mol} / \mathrm{l} \\
\text { acetate buffer }\end{array}$ & 5.52 & $\begin{array}{l}16.0 \\
20.0 \\
25.0 \\
30.0 \\
35.0\end{array}$ & $\begin{array}{c}227 \\
167 \\
140 \\
98.8 \\
97.2\end{array}$ & -9.68 & -9.02 \\
\hline \multirow{4}{*}{40} & $\begin{array}{l}0.005 \mathrm{~mol} / l \\
\text { acetate buffer }\end{array}$ & \multirow{4}{*}{5.50} & $\begin{array}{l}20.0 \\
25.0 \\
30.0 \\
35.0 \\
40.0\end{array}$ & $\begin{array}{l}249 \\
218 \\
193 \\
172 \\
153\end{array}$ & -4.37 & 9.79 \\
\hline & $\begin{array}{l}0.005 \mathrm{~mol} / l \\
\text { acetate buffer } \\
+0.01 \mathrm{~N} \mathrm{NaCl}\end{array}$ & & $\begin{array}{l}16.0 \\
20.0 \\
25.0 \\
30.0 \\
35.0\end{array}$ & $\begin{array}{l}263 \\
227 \\
201 \\
171 \\
144 \\
\end{array}$ & -5.52 & 5.72 \\
\hline & $\begin{array}{l}0.005 \mathrm{~mol} / l \\
\text { ac etate buffer } \\
+0.02 \mathrm{~N} \mathrm{NaCl}\end{array}$ & & $\begin{array}{l}16.0 \\
20.0 \\
25.0 \\
30.0 \\
35.0\end{array}$ & $\begin{array}{l}264 \\
233 \\
186 \\
162 \\
140\end{array}$ & -6.01 & 4.01 \\
\hline & $\begin{array}{l}0.005 \mathrm{~mol} / \mathrm{l} \\
\text { acetate buffer } \\
+0.04 \mathrm{~N} \mathrm{NaCl}\end{array}$ & & $\begin{array}{l}16.0 \\
20.0 \\
25.0 \\
30.0 \\
\end{array}$ & $\begin{array}{l}312 \\
240 \\
175 \\
135\end{array}$ & -10.5 & -11.2 \\
\hline
\end{tabular}

* Calculated on mole fraction basis. 


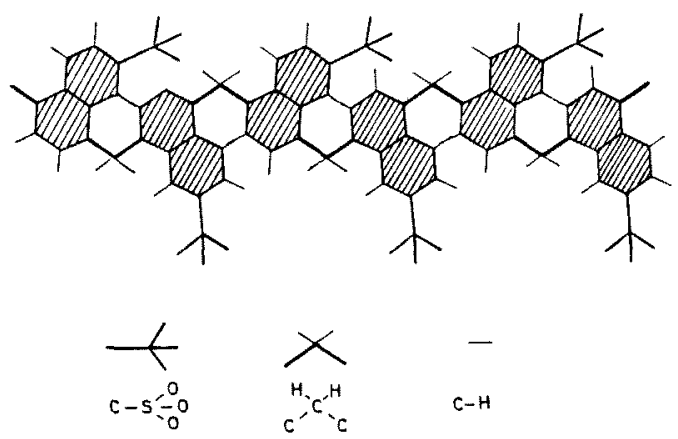

Fig. 6 An assumed conformation of $\beta$ NSF with higher degree of condensation in an extended form.

The figure was drawn using the bond lengths $\mathrm{C}-\mathrm{C}$ and $\mathrm{C}-\mathrm{H}$ in naphthalene, 1.40 and $1.08 \AA$, and $\mathrm{C}-\mathrm{S}$ and $\mathrm{S}-\mathrm{O}$ in sulfonic acid, $1.78^{11)}$ and $1.45 \AA^{(1)}$. respectively.

$\beta$ NSF with $N=3,12$ and 40 , respectively. As described before, $\beta$ NSF with $N=12$ and 40 behave as polyelectrolyte as shown in Fig. 5 but $\beta \mathrm{NSF}$ with $N=3$ does not so. For $\beta$ NSF with $N=3$, the thermodynamic parameters of the dye binding were only slightly changed on increasing of the concentration of the added salts (acetate buffer). On the other hand, for $\beta$ NSF with $N=12$ and 40 , the contribution of $\Delta H^{\circ}$ to the binding increased but that of $\Delta S^{\circ}$ decreased as the concentration of the added salt was increased. In the presence of the highest concentration of the added salt, the value of $\Delta S^{\circ}$ became negative as in the case of the binding by $\beta$ NSF with $N=2$ or 3 . This means that when $\beta$ NSF with higher $N, N=12-40$, is in a very compact conformation, the contribution of the hydrophobic bonding to the binding becomes very small as in the binding by $\beta$ NSF with $N=2$ or 3. The expanded conformation, where the successive naphthalene nuclei of $\beta$ NSF with large $N$ will lie as linear as possible, is favorable to the hydrophobic bonding.

\section{REFERENCES}

1) S. Heiman, Rev. Prog. Coloration, 11, 1 (1981)

2) K. Hattori and K. Konishi, Kogyo Kagaku Zasshi, 66, 59 (1963)

3) K. Hattori and Y. Tanino, Kogyo Kagaku Zasshi, 66, 55 (1963)

4) S. Fudano and K. Konishi, J. Chromatography, 56, 55 (1963)

5) K. Hattori and Y. Tanino, Kogyo Kagaku Zasshi, 67, 1576 (1964)

6) E. I. Valko, Rev. Prog. Coloration, 3, 50 (1972)

7) T. Shibusawa and F. Igarashi, Nippon Kagaku Kaishi, 1974, 1544 (1974)

8) B. Carroll and H. C. Cheung, J. Chem. Phys., $66,2585(1962)$

9) R. H. Peters, "Textile chemistry, volume I", Elsevier Publishing Company, Amsterdam/ London/New York, p109 (1967)

10) C. H. Giles, "The Theory of Coloration of Textiles", (C. L. Bird and W. S. Boston Ed.), Dyers Company Publication Trust, Bladford, p85 (1975)

11) A. W. Hanson, Acta Cryst., B29, 454 (1973)

\section{$\beta$ ナフタレンスルホン酸ホルマリン縮合物ナトリウム塩に対する}

非イオンアゾ色素の結合—結合平衡に対する縮合度の影響

\section{群馬大学工業短期大学部 涉沢崇男}

水に溶解したモデルアゾ分散染料 (Dye 1) と $\beta$ - + フタレンスルフォン酸ホルマリン縮合物ナトリウム塩 $(\beta \mathrm{NSF})$ との相互作用を高分子電解質化対する色菜の 結合平衡として取り扱い，結合平衡化対する $\beta \mathrm{NSF} の$ 縮合度 $(N)$ の影響を結合平衡の熱力学関数値加ら検討し た。結合定数 $(K)$ は $15-40^{\circ} \mathrm{C}$ で分光法で測定した。 $\beta N S F$ は合成品加 $N=2,3,4,5,7.2,12(N>9), 40$ $(N>9)$ の成分を分離して用いた。

$K$ の值は $N \approx 10$ 迄は $N$ の増加之共仁急激に増加し，そ の後次第に頭打ちとなった。てれは $\Delta S^{\circ}$ の寄与による。 $\Delta S^{\circ}$ の值は $N$ と共に增加し， $N=2,3,4$ では負であるが，
$N=12,40$ では正となった。 $A H^{\circ}$ は $N=2-40$ まですべ て負であったがその絶対値は $N$ と共汇減少した。てれよ $り$ ，結合反応汇対する Dye $1<\beta$ NSF の蹯水部分との 間の相互作用の寄与が $N$ の增加と共に增加して $\Delta S^{\circ}$ が增 加すると推論された。

$N=3,12,40$ の成分に対して結合反心に対する電解質 添加の影響を調べた。 $N=3$ の成分では添加電解質濃度 が增加して6結合反応の熱力学関数值は殆ど変化しない が $N=12,40$ では，電解質濃度が増加すると $\Delta H^{\circ}, \Delta S^{\circ}$ 共減少する。特に $\Delta S^{\circ}$ は正加負に変化する。て机は $N=12,40$ の成分が水中で高分子電解質として挙動する 
特性加ら説明された。

電解質濃度の低いところでは $\beta$ NSF $(N=12,40) 0$ 分

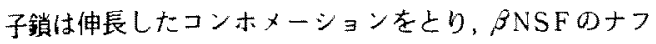
タレン核はなるべく直線状に並ばうとするので細長い形 をしたDye 1 と $\mathrm{NSF}$ との間の疎水結合の形成に纩好 都合となる。添加塩の濃度か高まると分子鎖はコンバク
トなコンホメーションとなり，蹯水結合の形成には不利 となるので $4 S^{\circ}$ は減少する。NO大きな J NSFではナ フタレン核加るる゙く直線状住ぶコンホーメイション

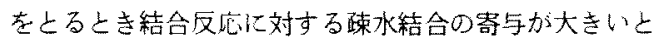
推諭された。 